\title{
Functional Silica Nanoparticles Synthesized \\ by Water-in-Oil Microemulsion Processes
}

Tangi AUBERT ${ }^{1}$, Fabien GRASSET ${ }^{1 *}$, Stéphane MORNET ${ }^{2}$, Etienne DUGUET ${ }^{2}$, Olivier CADOR $^{1}$, Stéphane CORDIER ${ }^{1}$, Yann MOLARD ${ }^{1}$, Valérie DEMANGE ${ }^{1}$, Michel MORTIER ${ }^{3}$, Hajime HANEDA ${ }^{4 *}$

${ }^{1}$ Université de Rennes 1, UMR «Science Chimiques de Rennes » UR1-CNRS 6226, Campus de Beaulieu, CS 74205, F-35042 Rennes Cedex, France.

${ }^{2}$ CNRS, Université de Bordeaux, Institut de Chimie de la Matière Condensée de Bordeaux, 87, avenue du Docteur Albert Schweitzer, F-33608 PESSAC Cedex, France.

${ }^{3}$ Ecole Nationale Supérieure de chimie de Paris, ENSCP, 11 rue P. et M. Curie, Paris, F-75005, France

${ }^{4}$ National Institute for Materials Science, Namiki 1-1, Tsukuba, Ibaraki 305-0044, Japan.

*Address:

Dr. Fabien GRASSET

Université de Rennes 1

Sciences Chimiques de Rennes, UMR UR1-CNRS 6226,

Equipe Chimie du Solide et Matériaux

CS 74205, 35042 Rennes CEDEX, FRANCE

Tel : +33(0)2 23236540

Fax: +33 (0)223235683

grasset@univ-rennes1.fr

http://scienceschimiques.univ-rennes1.fr/csm/personnel/f_grasset.html

Dr. Hajime HANEDA

Managing Director of Sensor Materials Center,

National Institute for Materials Science.

1-1 Namiki, Tsukuba, IBARAKI 305-0044, JAPAN

Tel: +81-29-860-4665

Fax: $+81-29-855-1196$

e-mail: haneda.hajime@nims.go.jp

http://www.nims.go.jp/senmc/en/index.html 


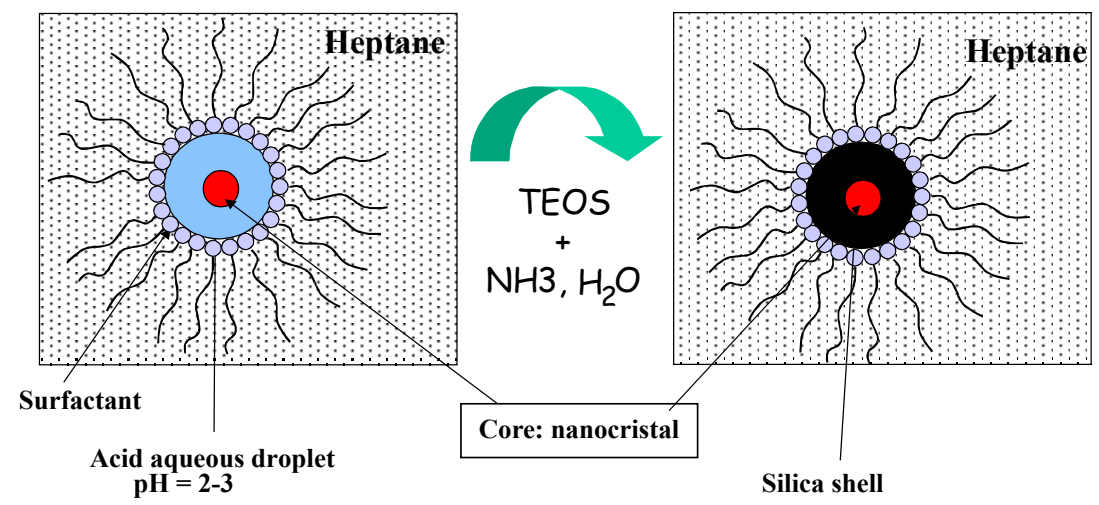

Colloid-in-Water-in-Oil (C/W/O) microemulsion is a wellsuitable confined reacting medium for the synthesis of structured functional nanoparticles of controlled size and shape. 


\begin{abstract}
Water-in-Oil (W/O) microemulsion is a well-suitable confined reacting medium for the synthesis of structured functional nanoparticles of controlled size and shape. During the last decade, it allowed the synthesis of multi-functional silica nanoparticles with morphologies as various as core-shell, homogenous dispersion or both together. The morphology and properties of the different intermediates and final materials obtained through this route are discussed in the light of UV-VisNIR spectroscopy, dynamic light scattering (DLS) and X-ray diffraction (XRD), transmission electron microscopy (TEM), scanning electron microscopy (SEM) and magnetometer SQUID analysis.
\end{abstract}




\section{Introduction}

Multi-functional silica nanoparticles (NPs) have tremendous potential applications as magnetic indicators and/or photon sources for a number of biotechnological and information technologies. Indeed, the chemistry of silica gained recently in interest in the design of new nanosized particles with functional architecture for applications in biotechnology and photonics [1, 2]. Silica NPs are actually very promising candidates in the fields of bio-labelling, imaging, separation, diagnosis and therapy [3-5] and band-gap photonic materials when assembled in colloidal crystals $[6,7]$. These applications all require size-controlled, monodispersed, bright and/or magnetic NPs that can be specifically conjugated to biological macromolecules or arranged in higher ordered structures. Also the preparation of such functional NPs involves a very good understanding of the influence of the synthesis parameters in order to control the properties of the final product such as size, morphology, effects of the shell on the core particle, etc. Considering those demands, synthesis in microemulsions appeared as a promising route for the preparation of such complex silica NPs with a diameter below $100 \mathrm{~nm}$ [8]. Such a confined environment was involved during the last decade in our research activities to synthesize silica NPs with several types of nanostructures and properties [9-16]. This contribution summarizes our own results on the synthesis through water-inoil (W/O) microemulsion and characterization of core-shell morphologies $\mathrm{M} @ \mathrm{SiO}_{2}\left(\mathrm{M}=\gamma-\mathrm{Fe}_{2} \mathrm{O}_{3}\right.$, $\left.\mathrm{ZnFe}_{2} \mathrm{O}_{4}, \mathrm{CeO}_{2}, \mathrm{Cs}_{2} \mathrm{Mo}_{6} \mathrm{Br}_{14}\right)$ in the form of colloids or functional thin films. The different materials were studied by UV-Vis-NIR spectroscopy and dynamic light scattering (DLS) and characterized by X-ray diffraction data (XRD), transmission electron microscopy (TEM), scanning electron microscopy (SEM) and magnetometer SQUID analysis.

\section{Microemulsions for $\mathrm{M} @ \mathrm{SiO}_{2}$ NPs synthesis}

Microemulsions are thermodynamically stable dispersions of two immiscible fluids stabilized by the arrangement of surfactant molecules at the interface [17] : water-in-oil (W/O), oilin-water $(\mathrm{O} / \mathrm{W})$ and water-in-supercritical $\mathrm{CO}_{2}\left(\mathrm{~W} / \mathrm{sc}-\mathrm{CO}_{2}\right)$. Three factors characterize a microemulsion: transparency (optical isotropy), droplet size (6 to $80 \mathrm{~nm}$ ) and stability (thermodynamic) [18]. This microreview focuses on w/o microemulsions for the preparation of inorganic nanoparticles, which consist of nanodroplets of pseudo-water phase dispersed in an oil phase and stabilized in spherical reverse micelles created by the surfactant molecules. Those water droplets can then be considered as nanoreactors and by controlling the molar ratio of the mixture oil/water/surfactant, it is possible to predetermine the size and shape of those droplets and, as a consequence, to tailor the size and shape of the final product $[19,20]$. Let us point out that 
microemulsion is a dynamic system because of the Brownian motion of the water droplets. When

two droplets collide, they can fuse and interchange reactants [21, 22] (scheme 1). This phenomenon is called intermicellar exchange and is strongly dependent on the elasticity of the surfactant film [18]. Then classically the microemulsion exchange characteristic time $\tau_{\mathrm{ex}}$ is in the range $\approx 10$ $\mu \mathrm{s}<\tau_{\mathrm{ex}}<1 \mathrm{~ms}$ depending on the film flexibility i.e. the used surfactant [22]. Nevertheless, the exchange of particles (core nanoparticles and/or condensed nanoparticles) is generally inhibited, depending on the size of the particles, by the inversion of the film curvature $[21,22]$. Although no information was collected in the synthesis described here about the importance of these intermicellar exchange phenomena and the film flexibility, it is expected to act up on reactants exchange during the hydrolysis process [10].

Microemulsion was first used at the end of the 80 's by several groups in order to control the synthesis of monodispersed $\mathrm{SiO}_{2}$ nanoparticles [23-25]. The synthesis of silica requires an alkoxyde precursor, water and often a base for catalyzing the hydrolysis and condensation steps [13, 23-26]. The size of the monodispersed silica nanoparticles can be controlled from few ten nanometers to hundred nanometers. Moreover, since Chang et al. proposed to use microemulsion process to synthesize CdS@ $\mathrm{SiO}_{2}$ nanoparticles [8], a lot of studies have been published on the synthesis of functional silica nanoparticles with magnetic and/or optical properties [10, 12, 14, 15, 27-37]. In the most common microemulsion processes, nanoparticles are obtained by simple mixing of two waterin-oil microemulsions, one containing a salt or a complex of metal (reactant \#1) while the other contains a precipitating agent (reactant \#2) [see scheme 2 from 38]. Nevertheless, a major drawback with this process remains the effect of the reactants and products on the microemulsion stability domain, particularly the metal concentration in the aqueous pseudo-phase used for precipitation reactions $[18,21,22]$.

That is why, to avoid this precipitation process, we have proposed an original method to design functional silica nanoparticles, using a colloid-in-water dispersion as the starting water pseudo-phase instead of the metal salt aqueous solution (see scheme 3) [9-12, 14-16]. This colloidal suspension allows the increase of the metal concentration without destabilizing the microemulsion, and avoids a subsequent calcination stage $[39,40]$. All the syntheses reported in this section were designed to prepare $\mathrm{M} @ \mathrm{SiO}_{2}$ monodispersed nanoparticles by $\mathrm{W} / \mathrm{O}$ microemulsions. Those syntheses are based on a sol-gel reaction in two steps confined into the water nanodroplets: (i) hydrolysis of an alkoxyde precursor, (ii) polycondensation of the hydrolyzed monomers.

Those reactions occur inside the pseudo-water phase droplets and at their interfaces with the oil phase. In more details, our W/O microemulsion process is based on three major reactants: an oil phase, a surfactant with a possible co-surfactant, and complex water phase (acid colloid, TEOS and ammonia). In all the synthesis described here, $n$-heptane was always chosen as the oil phase 
because of its low toxicity in comparison with other similar reactants like hexane. Many previous

publications report studies on the influence of the surfactant depending on its alkyl chain length, head group size or ionic character. It is well assumed that the choice of the surfactant has a critical influence on the final shape and size of the product synthesized in the microemulsion [18, 22]. It is also recognized that using a co-surfactant leads to a higher fluidity of the interface film between the droplets and the oil phase, resulting in a higher rate of intermicellar exchange, but also in a higher curvature of the droplets, resulting in smaller final particles [41]. For most of the syntheses described here, the chosen non-ionic surfactant was Brij30® (Polyoxyethylene (4) lauryl ether), since it showed the best results in preliminary trials avoiding the use of any co-surfactant. By using Brij30 ${ }^{\circledR}$ as the surfactant or co-surfactant, the temperature should be kept below $25^{\circ} \mathrm{C}$ in order to avoid any possible thermally induced phase inversion. The precursor was chosen to be tetraethylorthosilicate (TEOS) since it can be easily handled in the ambient air, contrary to other precursors like the air-sensitive tetramethoxysilicate (TMOS). As explained below, and contrary to the other published methods, in the present process, the hydrolysis of TEOS was firstly acid catalyzed thanks to the acidic water colloids whereas condensation was base catalyzed with final addition of ammonia. Ammonia has been chosen since it preferentially dissolves in the water phase and easily decomposes without any possible contaminant, contrary to other bases like sodium hydroxide which releases $\mathrm{Na}^{+}$ions that can be adsorbed at the surface of the synthesized particle and form sodium silicate.

The main interest of this proposed $\mathrm{W} / \mathrm{O}$ microemulsion process is the preparation of multifunctional silica coated nanocrystals $\mathrm{M} @ \mathrm{SiO}_{2}$. Several types of $\mathrm{M}$ nanocrystal cores with interesting catalytic, magnetic or luminescence properties have been coated with silica, in order to get functional nanoparticles such as: $\mathrm{ZnFe}_{2} \mathrm{O}_{4} @ \mathrm{SiO}_{2}$ [10], $\mathrm{CeO}_{2} @ \mathrm{SiO}_{2}$ [12], $\mathrm{Cs}_{2}\left[\mathrm{Mo}_{6} \mathrm{X}_{14} @ \mathrm{SiO}_{2}\right.$ $\left(\mathrm{X}=\mathrm{Cl}, \mathrm{Br}\right.$, and I) [14] and $\gamma-\mathrm{Fe}_{2} \mathrm{O}_{3}-\mathrm{Cs}_{2} \mathrm{Mo}_{6} \mathrm{Br}_{14} @ \mathrm{SiO}_{2}$ [15]. Detailed description of synthesis process are given in cited corresponding papers. In all those cases, the major key-point is the stability of the starting acidic aqueous sols containing the core. Then they play the role of the aqueous phase in the heptane/surfactant/water mixture with a precisely controlled molar ratio defining the microemulsion. By choosing an appropriate concentration of the sol, it is possible to control the number of nanocrystals as core embedded in the silica nanoparticles. After their addition, organophilic TEOS molecules are more readily dissolved in heptane than in the aqueous droplets. While diffusing into the acidic aqueous droplets, TEOS is hydrolyzed:

$\mathrm{Si}-\left(\mathrm{OC}_{2} \mathrm{H}_{5}\right)_{4}+m \mathrm{H}_{2} \mathrm{O} \rightarrow \mathrm{Si}-\left(\mathrm{OC}_{2} \mathrm{H}_{5}\right)_{4-m}(\mathrm{OH})_{m}+m \mathrm{C}_{2} \mathrm{H}_{5} \mathrm{OH}$

It is well-known that the number of nuclei will increase with rapid hydrolysis [26]. Thus, as for this microemulsion technique an acid catalysis is involved in the first step, a large number of nuclei are quickly generated resulting in a decrease of the final particle size. After completion of the 
hydrolysis process, aqueous ammonia solution is added to the mixture in order to base-catalyze the

condensation of the hydrolyzed monomers inside the droplets by increasing the $\mathrm{pH}$. The condensation induces the formation of $\mathrm{Si}-\mathrm{O}-\mathrm{Si}$ or $\mathrm{Si}-\mathrm{OH}-\mathrm{Si}$ bonds via olation, oxolation or alcoxolation. According to Finie et al. [26], after 30' in acidic condition, all the monomeric species of TMOS have been hydrolyzed and consequently have migrated into the droplets for condensation and formation of $\mathrm{SiO}_{2}$. Base catalysis of silica sol-gel reactions promotes condensation. Rapid condensation results in fast consumption of all precursors inside the micelles and in the formation of a dense silica structure. Moreover, a high dissolution rate ensures the production of spherical and dense particles by the ripening of potential aggregates formed during the collision of droplets containing nuclei. This leads to the production of a fairly homogeneous and monodisperse population of particles which are subsequently washed with $n$-heptane, ethanol and acetone in order to remove oil and surfactants. The particles are separated from the liquid phase by centrifugation and finally dried in a vacuum oven at $60^{\circ} \mathrm{C}$ or simply in the air at room temperature. The procedure for the $\mathrm{CeO}_{2} @ \mathrm{SiO}_{2}$ nanoparticules synthesis is summarized in figure 1 [12]. The scattering is due to the size of the $\mathrm{CeO}_{2}$ core (diameter centered around $40 \mathrm{~nm}$, see figure 2).

\section{Characterization of the prepared NPs}

\subsection{Size and morphology}

As previously explained, one of the most important issue in this microemulsion process is the stability of the colloid-in-water dispersion used as starting pseudo-water phase. Dynamic Light Scattering (DLS) technique is widely used to characterize the size of the performed nanocrystals as well as the size of the droplets in the microemulsion since this parameter is reliable to that of the final particles. The DLS technique measures the particle or droplet light diffusion due to Brownian motion and relates it to its hydrodynamic diameter by using the Stokes-Einstein equation. This technique gives useful informations about the hydrodynamic diameter and polydispersity of the nanocrystals dispersed in the droplets. An example is given in figure 2 showing two different $\mathrm{CeO}_{2}$ dispersions with a hydrodynamic diameter of $7 \mathrm{~nm}$ and $40 \mathrm{~nm}$ respectively [12].

Microscopy techniques such as Scanning Electron Microscopy (SEM) or High resolution Transmission Electron Microscopy (HRTEM) are also useful to get data about the shape and morphology of the prepared silica nanoparticles. The size of the monodispersed silica nanoparticles can range from few ten-nanometers to hundred nanometers with a good control as observed by SEM in figure 3a. HRTEM with HAADF-STEM mode (High-Angle Annular Darkfield-Scanning TEM) in particular is very powerful to determine the arrangement of the core particles within the 
silica shell. Figure $3 \mathrm{~b}$ shows examples of ferrite nanocrystals and $\left[\mathrm{Mo}_{6} \mathrm{Br}_{14}\right]^{2-}$ clusters embedded in a silica particle [15].

\subsection{Magnetic properties}

For nanoparticles with interesting magnetic properties $\left(\gamma-\mathrm{Fe}_{2} \mathrm{O}_{3} @ \mathrm{SiO}_{2}[11] ; \mathrm{ZnFe}_{2} \mathrm{O}_{4} @ \mathrm{SiO}_{2}\right.$ $[10,42]$ and $\left.\gamma-\mathrm{Fe}_{2} \mathrm{O}_{3}-\mathrm{Cs}_{2} \mathrm{Mo}_{6} \mathrm{Br}_{14} @ \mathrm{SiO}_{2}[15]\right)$, the evolution of magnetization versus temperature was studied in both DC (ZFCM (Zero Field Cooled Magnetization) and FCM (Field Cooled Magnetization)) and AC modes with a SQUID magnetometer. Through this study, we demonstrated clearly that the surface of $\mathrm{SiO}_{2}$ induced systems with a minimum degree of aggregation and modified strongly the interactions between magnetic nanocrystals and most likely surface effects. After the coating of each magnetic nanocrystals, significant changes in the magnetic behavior could be highlighted, particularly with regard to the blocking temperature [10, 42].

As first example, a system consisting of aggregated or silica coated zinc ferrite nanocrystals was studied using DC and AC magnetization measurements $[10,42]$. The temperature dependence of the ZFCM and FCM curves of an aggregated or silica coated sample recorded under 10 Oe are presented in figure 4. The ZFCM increases with increasing temperature, passing through a broad maximum at $T \max =32.5 \mathrm{~K}$. On cooling, the FCM coincides with the ZFCM down to $30 \mathrm{~K}$ and then both curves significantly differ on cooling. As a result, the FCM also passes through a maximum at Tmax, but much less pronounced than in the ZFCM mode. One of the striking features of the silica coated nanocrystals is that the broad maximum on the FCM curve has disappeared compared to the uncoated ones. The FCM increases as the temperature is lowered and tends to saturate in the low-temperature limit as usual for superparamagnetic entities (figure 4).

For the aggregated nanocrystals, a superparamagnetic-super-spin-glass phase transition at $\mathrm{Tg}$ was identified and explained clearly these behaviors. The relaxation time diverges at $\mathrm{Tg}$ and the nonlinear susceptibility shows an abrupt increase. This critical behavior vanishes when the nanocrystals are not in close contact in case of silica coating particles or dispersed sols [10, 42]. Moreover, the first observation of the memory effect in oxide nanocrystals is identical to what has been already discovered in canonical spin-glass, supporting the existence of a true thermodynamic transition in agglomerated zinc ferrite magnetic nanoparticles (figure 5).

As second example, it was demonstrated that the silica coating of single $\gamma-\mathrm{Fe}_{2} \mathrm{O}_{3}$ nanocrystal induced a shift of the transition temperature of maghemite $\left(\gamma-\mathrm{Fe}_{2} \mathrm{O}_{3}\right)$ into hematite $\left(\alpha-\mathrm{Fe}_{2} \mathrm{O}_{3}\right)$. Indeed, classically maghemite turns hematite at $450^{\circ} \mathrm{C}$ [43] while after coating it remains stable until $1000^{\circ} \mathrm{C}$ [11]. The magnetic studies realized on non-coated and coated nanocrystals have shown (i) a shift to lower value of the blocking temperature as observed in the magnetic curve 
recorded as a function of temperature by cooling the sample in zero-field (ZFCM) revealing a significant decline of magnetic interactions between the nanocrystals after coating; ii) the preservation of inverse spinel structure with ferromagnetic behavior up to $1000^{\circ} \mathrm{C}$ (figure 6). Moreover, we should notice that in addition to these magnetic characterizations, studies by X-ray diffraction showed that the silica shell acts as well as a diffusion barrier up to $1000^{\circ} \mathrm{C}$.

In conclusion to this part, it has been clearly shown through several examples that the average magnetic behavior for magnetic nanocrystals depends on their environment and that the magnetic properties of these nanocrystals at low temperature are essentially governed by the interface particle-habitat.

\section{Potential application of the prepared NPs}

\subsection{Superscratch-resistant glass [13]}

Silica nanoparticles can also be used to prepare functional thin films. Tartivel et al. made thin films of pure silica particles on glass slides in order to get superscratch-resistant transparent glasses [13]. Thin films were obtained by dip-coating of a soda-lime silica (SLS) glass slide directly in the microemulsion. Then, the samples were heated for $15 \mathrm{~min}$ at $400^{\circ} \mathrm{C}$ in air, both to drive silica condensation and particle formation and to remove the organic phases. Indentation (Vickers) scratching experiments were conducted to estimate the resistance toward mechanical damage, with a load increasing from 0 to $2.5 \mathrm{~N}$ and a loading rate of $0.01 \mathrm{~N}^{-\mathrm{s}^{-1}}$. The loading cycle typically leads to three different regimes as the load increases: the micro-ductile regime, the micro-cracking regime and the micro-abrasive regime. Figure 7 shows pictures of the resulting glass slides after application of this loading cycle for both coated and uncoated samples. It appeared that coated samples show a longer micro-ductile regime, with the micro-cracking and micro-abrasive regimes occurring at higher load compared to uncoated SLS slides. As a consequence, the coated samples did not show any sub-surface lateral crack and remain optically transparent, while the uncoated samples exhibit large cracks that scatter light.

\section{2. $\mathrm{CeO}_{2} @ \mathrm{SiO}_{2}$ anti-UV nanoparticles [12]}

$\mathrm{CeO}_{2} @ \mathrm{SiO}_{2}$ dispersible nanopowders and thin films were prepared with the same procedure as previously described. The $\mathrm{CeO}_{2}$ nanocrystals display very promising UV-absorption properties. However, three important issues must be previously solved: a refractive index equal to 2.50 at $\lambda=$ $550 \mathrm{~nm}$, a strong yellow color [44] and catalytic oxidation properties [45]. One way to reduce the 
refractive index of such nanoparticles is to coat them by a thin layer of a material displaying a much

lower refractive index such as silica $(\mathrm{n}=1.45)$ [46]. Another way is to replace a part of the $\mathrm{CeO}_{2}$ network anionic $\mathrm{O}^{2-}$ ion by low-polarizability anions such as $\mathrm{F}^{-}$[44].

In our recent study, it was possible to prepare core-shell and monodispersed spherical silica nanoparticles with a core of $\mathrm{CeO}_{2}$ by the technique of w/o microemulsion. The thickness of the silica shell could be controlled and ranges from 5 to $20 \mathrm{~nm}$ [12]. The use of concentrated colloidal solutions of $\mathrm{CeO}_{2}$ allowed preparing $\mathrm{CeO}_{2} @ \mathrm{SiO}_{2}$ systems containing more than $25 \%$ (weight mass) of $\mathrm{CeO}_{2}$. Figure 8 shows UV-Vis absorption spectrum of those prepared $\mathrm{CeO}_{2} @ \mathrm{SiO}_{2}$ nanopowders, which confirms the absorption in the UV domain. These functional nanoparticles could be useful (i) for reinforcement of glassy surface materials (ii) during the chemical-mechanical planarization (CMP) process in semiconductor industry.

\section{3. $\gamma-\mathrm{Fe}_{2} \mathrm{O}_{3}-\mathrm{Cs}_{2} \mathrm{Mo}_{6} \mathrm{Br}_{14} @ \mathrm{SiO}_{2}$ nanoparticles for bio-imaging [15]}

Nanoparticles with simultaneous luminescent and magnetic properties should find interesting applications in nano-biotechnologies [47-71]. Magnetic properties could make the particle suitable for bio-imaging techniques such as Magnetic Resonance Imaging (MRI) or hyperthermia therapy [72] and luminescence properties could allow an optical tracing of the particles [73]. Moreover silica coated particles are good candidates for such applications since silica is a particularly inert material, it could prevent the diffusion of toxic metal cations from the cores and its surface could be easily functionalized by further treatment in order to get a bio-compatible, targetable and dispersed material at neutral $\mathrm{pH}$. Indeed, for imaging applications, the current probes (organic dyes or Quantum Dots) encounter several challenges, such as limited tissue penetration and potential toxicity. To address these needs, it is important to develop new low toxicity near-infraredemitters coupled with silica coating in order to improve tissue penetration depth and colloidal stability [14, 15, 37, 74-76]. Recently, we have demonstrated the preparation of stable colloidal acidic sols containing $\left[\mathrm{Mo}_{6} \mathrm{Br}_{14}\right]^{2-} 1 \mathrm{~nm}$ size cluster units and their dispersion in silica to form luminescent $\mathrm{Cs}_{2} \mathrm{Mo}_{6} \mathrm{Br}_{14} @ \mathrm{SiO}_{2}$ nanoparticules [14]. Let us recall that $\left[\mathrm{Mo}_{6} \mathrm{Br}_{14}\right]^{2-}$ units are based on a rigid $\mathrm{Mo}_{6} \mathrm{Br}_{8}^{\mathrm{i}}$ cluster core additionally bonded to six apical ligands $\left(\mathrm{Br}^{\mathrm{a}}\right)$. They are obtained by solid state chemistry route and can be used as soluble building blocks either directly or after functionalization, for the synthesis of various hybrid architectures including dendrimers and extended molecular arrays [77-79]. Particularly interesting are their photoluminescent properties characterized by a large emission region in the red and near infrared window $(580-900 \mathrm{~nm})[80,81]$. Such wavelengths are weakly absorbed by tissues and blood constituting the human body [76, 81]. Bifunctionnal magnetic and luminescent $\gamma-\mathrm{Fe}_{2} \mathrm{O}_{3}-\mathrm{Cs}_{2} \mathrm{Mo}_{6} \mathrm{Br}_{14} @ \mathrm{SiO}_{2}$ structured nanoparticles were 
recently obtained by a one pot synthesis by $\mathrm{C} / \mathrm{W} / \mathrm{O}$ microemulsion [15]. $\gamma-\mathrm{Fe}_{2} \mathrm{O}_{3}$ magnetic nanocrystals are located in the core of the nanoparticle and $\left[\mathrm{Mo}_{6} \mathrm{Br}_{14}\right]^{2-}$ are homogeneously dispersed in the silica matrix.

Figure 9 shows the emission spectrum of the particles after an irradiation at $\lambda_{\mathrm{exc}}=546 \mathrm{~nm}$ producing an intense red luminescence corresponding to the emission of the $\left[\mathrm{Mo}_{6} \mathrm{Br}_{14}\right]^{2-}$ units. The insert in figure 9 shows nicely the effect of an applied magnetic field along the wall of a cell containing a dispersion of such nanoparticles in an aqueous ethanolic solution $(\mathrm{pH}=8)$ as a function of time. The magnetization of those particles was also checked in both ZFC and FC modes, and the magnetic behavior was found to be typical of moderately monodispersed superparamagnetic ferrite nanocrystals dispersed in silica matrix [15].

\section{Conclusion and Perspectives}

This work has demonstrated that the W/O microemulsion method is sufficiently robust and efficient to be complementary with other techniques such as the Stöber's method for the preparation of monodisperse functional silica particles with a diameter below $100 \mathrm{~nm}$. This highly reproducible technique can be used to prepare successfully complex $\mathrm{M} @ \mathrm{SiO}_{2}$ nanoparticles $\left(\mathrm{ZnFe}_{2} \mathrm{O}_{4} @ \mathrm{SiO}_{2}, \gamma\right.$ $\mathrm{Fe}_{2} \mathrm{O}_{3} @ \mathrm{SiO}_{2}, \mathrm{CeO}_{2} @ \mathrm{SiO}_{2}, \mathrm{Cs}_{2} \mathrm{Mo}_{6} \mathrm{Br}_{14} @ \mathrm{SiO}_{2}$ ) with a high control in shape and size in the nanometric range $(<60 \mathrm{~nm})$. The advantage of this $\mathrm{W} / \mathrm{O}$ microemulsion process as compared to the Stöber's method is well demonstrated in the preparation of monodispersed bi-functional nanoparticles with complex architecture like $\gamma-\mathrm{Fe}_{2} \mathrm{O}_{3}-\mathrm{Cs}_{2} \mathrm{Mo}_{6} \mathrm{Br}_{14} @ \mathrm{SiO}_{2}$ nanoparticles. Moreover, this method should be very useful for the encapsulation of polymer particles or unstable particles in acidic media.

Such particles present a real interest for a wide range of applications such as bionanotechnology, catalysis, mechanical reinforcement of substrates, etc... However, further improvements remain to be done like, for example, bio-imaging applications: the actual excitation wavelengths used to observe an efficient luminescence of the clusters are located in the absorption band of tissues and organs constituting the human body. One solution could be to combine those clusters with rare earth elements to form an up-conversion system and allow the excitation of the clusters at low-energy wavelengths which would not be absorbed by the human body (e.g. Near-IR range). Finally, the toxicity of such particles should also be thoroughly investigated.

\section{References}


1. Burns, O. Hooisweng, U. Weisner, Chem. Soc. Rev., 35 (2006) 1028-1042

2. L. Wang, W. Zhao, W. Tan, Nano Res., 1(2) (2008) 99-115

3. J. Yan, M.C. Estévez, J.E. Smith, K. Wang, X. He, L. Wang, W. Tan, NanoToday, 2(3) (2007) 44-50

4. B.G. Trewyn, I.I. Slowing, S. Giri, H.T. Chen, V.S.Y. Lin, Acc. Chem. Res., 40 (2007) 846853

5. I.I. Slowing, B.G. Trewyn, V.S.L. Lin, J. Am. Chem. Soc., 129 (2007) 8845-8849

6. P. Massé, G. Pouclet, S. Ravaine, Adv. Mater., 20 (2008) 584-587

7. J. Ge, J. Yin, Adv. Mater., 20(18) (2008) 3485-3491

8. S.-Y. Chang, L. Liu, S. A. Asher, J. Am. Chem. Soc., 116 (1994) 6139-4744

9. S. Mornet, F. Grasset, E. Duguet, J. Portier, Ferrites: Proceedings of the $8^{\text {th }}$ International Conference on Ferrites (ICF8), Kyoto and Tokyo Japan, The Japan Society of Powder and Powder Metallurgy (2000) 766

10. F. Grasset, N. Labhsetwar, D. Li, D. C. Park, N. Saito, H. Haneda, O. Cador, T. Roisnel, S. Mornet, E. Duguet, J. Portier, J. Etourneau, Langmuir 18 (2002) 8209-8216

11. S. Mornet, F. Grasset, J. Portier, E. Duguet, Europ. Cell Mater., 3(2) (2002)110

12. F. Grasset, R. Marchand, A.-M. Marie, D. Fauchadour, F. Fajardie, J. Colloid Interface Sci. 299 (2006) 726-732

13. R. Tartivel, E. Reynaud, F. Grasset, J. C. Sangleboeuf, T. Rouxel, J. Non-Cryst. Solids 353 (2007) 108-110

14. F. Grasset, F. Dorson, S. Cordier, Y. Molard, C. Perrin, A.-M. Marie, T. Sasaki, H. Haneda, Y. Bando, M. Mortier, Adv. Mater. 20 (2008) 143-148

15. F. Grasset, F. Dorson, Y. Molard, S. Cordier, V. Demange, C. Perrin, V. Merchi-Artzner, H. Haneda, Chem.Comm. 39 (2008) 4729-4731

16. S. Cordier, F. Dorson, F. Grasset, Y. Molard, B. Fabre, H. Haneda, T. Sasaki, M. Mortier, S.Ababou-Girard and C. Perrin, J. Cluster Sci., 20(1) 2009 9-21

17. J.H. Schulman, W. Stoeckenius, L.M. Prince, J. Phys. Chem., 63 (1959) 1677-1680

18. Kumar P. and Mittal K.L., Handbook of Microemulsion Science and Technology, by Marcel Dekker, Inc., New-York, 1999.

19. M. P. Pileni, J. Phys. Chem. C, 111 (26) (2007) 9019-9038

20. M. Boutonnet, S. Lögdberg, E. E. Svensson, Curr. Op. Colloid Inter. Sci., 13 (2008) 270286

21. M. A. Lopez-Quintela, Curr. Op. Colloid Inter. Sci. 8 (2003) 137-144 
22. M. A. Lopez-Quintela, C. Tojo, M. C. Blanco, L. Garcia Rio, J. R. Leis, Curr. Op. Colloid Inter. Sci. 9 (2004) 264-278

23. H. Yamauchi, T. Ishikawa, S. Kondo, Colloids Surf., 37 (1989) 71-80

24. K. Osseo-Asare, F.J. Arriagada, Colloids Surf., 50 (1990) 321

25. P. Espiard, J. E. Mark, A. Guyot, A. Polym. Bull., 24 (1990) 173

26. K. S. Finnie, J. R. Bartlett, C. J. A. Barbe, L. Kong, Langmuir, 23 (2007) 3017-3024

27. T. Li, J. Moon, A. A. Morrone, J. J. Mecholsky, D. R. Talham, J. H. Adair, Langmuir, 15 (1999) 4328-4334

28. S. Santra, R. Tapec, N. Theodoropoulou, J. Dobson, A. Hebard, W. Tan, Langmuir, 17 (2001) 2900-2906

29. T. Tago, T. Hatsuta, K. Miyajima, M. Kishida, S. Tashiro, K. Wakabayashi, J. Am. Ceram. Soc., 85(9) (2002) 2188-2194

30. C.R. Vestal, Z.J. Zhang, Nano Lett., 3(12) (2003) 1739-1743

31. M. Darbandi, R.Thomann, T. Nann, Chem. Mater., 17 (2005) 5720-5725

32. Y. Li, X. L. Zhang, R. Qiu, R. Qiao, Y. S. Kang, J. Phys. Chem. C, 111 (2007) 10747-10750

33. C.-W. Lu, Y. Hung, J.-K. Hsiao, M. Yao, T.-H. Chung, Y.-S. Lin, S.-H. Wu, S.-C. Hsu, H.M. Liu, C.-Y. Mou, C.-S. Yang, D.-M. Huang, Y.-C. Chen, Nano Lett., 7(1) (2007) 149-154

34. D. S. Mathew, R.-S. Juang, Chem. Eng. J., 129 (2007) 51-65

35. T. T. Tan, S. T. Selvan, L. Zhao, S. Gao, J. Y. Ying, Chem. Mater., 2007, 19, 3112-3117

36. J. Lee, Y. Lee, J.K.Youn, H.B. Na, T. Yu, H. Kim, S.-M. Lee, Y.-M. Koo, J. H. Kwak, H.

G. Park, H. N. Chang, M. Hwang, J.-G. Park, J. Kim, T. Hyeon, Small, 4 (2008) 143 - 152

37. Z. Liu, G. Yi, H. Zhang, J. Ding, Y. Zhang, J. Xue, Chem. Comm., (2008) 694-696

38. K. Holmberg, J. Colloid Inter. Sci., 274 (2004) 355-364

39. T. Tago, S. Tashiro, Y. Hashimoto, K. Wakabayashi, M. Kishida, J. Nanoparticle Res., 5 (2003) 55

40. Y. Kobayashi, M. Horie M. Konno B. Rodriguez-Gonzalez, L.M. Liz-Marzan, J. Phys.

Chem. B, 107(30) (2003) 7420-7425

41. J. Eastoe, M. J. Hollamby, L. Hudson, Adv. Colloid Interface Sci. 128-130 (2006) 5-15

42. O. Cador, F. Grasset H. Haneda, J. Etourneau, J. Magn. Magn. Mater., 268 (2004) 232-236

43. In 'De la solution a' l'oxyde', ed. J. P. Jolivet, 1994, InterEditions,CNRS Edition, Paris, ISBN 2729605266.

44. L. Sronek, J. Majimel, Y. Kihn, Y. Montardi, A. Tressaud, M. Feist, C. Legein, J.-Y.

Buzare, M. Body, A. Demourgues, Chem. Mater., 19 (2007) 5110-5121

45. S. Yabe and S. Momose, J. Soc. Cosmet. Chem., Jpn., 32 (1998) 372

46. Marchet N, Thesis of the University of Tours, 2008 
47. F. Grasset, S. Mornet, A. Demourgues, J. Portier, J. Bonnet, A. Vekris, E. Duguet, J. Magn. Magn. Mater., 234 (2001) 409-418

48. X. Hong, J. Li, M. Wang, J . Xu W. Guo, J. Li, Y. Bai, T. Li, Chem. Mater., 16 (2004) 40224027

49. D. Wang, J. He, N. Rosenzweig, Z. Rosenzweig, Nano Lett., 4(3) (2004) 409-413

50. H.Y. Xie, C. Zuo, Y. Liu, Z.L. Zhang, D.W. pang, X.L. Li, J.P. Gong, C. Dickinson, W. Zhou, Small, 5 (2005) 506-509

51. H. Kim, M. Achermann, L.P. Balet, J.A. Hollingsworth, V. I. Klimov, J. Am. Chem. Soc., 127 (2005) 544-546

52. D.K. Yi, T. Selvan, S.S. Lee, G.C. Papaefthymiou, D. Kundaliya, J. Y. Ying, J. Am. Chem. Soc., 127 (2005) 4990-4991

53. L. An, Z. Li, Z. Wang, J. Zhang, B. Yang, Chem. Let., 34(5) (2005) 652-653

54. W.B. Tan, Y. Zhang, Adv. Mater., 17 (2005) 2375-2380

55. L. Li, J. Ren, J. Solid State Chem., 179 (2006) 1814-1820

56. M.N. Rhyner, A.M. Smith, X. Gao, H. Mao, L. Yang, S. Nie, Nanomedecine, 1(2) (2006) 209-217

57. T. R. Sathe, A. Agrawal, S. Nie, Anal. Chem., 78 (2006) 5627-5632

58. S.Y. Mak, D.H. Chen, Chem. Let., 35(10) (2006 )1116-1117

59. V. Salgueiriña-Maceira, M.A. Correa-Duarte, M. Spasova, L.M. Liz-Marzan, M. Farle, Adv. Func. Mater., 16 (2006) 509-514

60. G.H. Du, Z.L. Liu, Q.H. Lu, X. Xia, L.H. Jia, K.L. Yao, Q. Chu, S. M. Zhang, Nanotechnology, 17 (2006) 2850-2854

61. G. Beaune, B. Dubertret, O. Clément, C. Vayssettes, V. Cabuil, C. Ménager, Angew. Chem. Int. Ed., 46 (2007) 1-5

62. S.-Y. Yu, H.-J. Zhang, J.-B. Yu, C. W., L.-N. Sun, W.-D. Shi, Langmuir, 23 (2007) 78367840

63. V. Salgueirino-Maceira and M. A. Correa-Duarte, Adv. Mater., 2007, 19, 4131

64. W. Lu, Y. Hung, J. K., Hsiao, M. Yao, T. H. Chung, Y. S. Lin, S. H. Wu, S. C. Hsu, H. M. Liu, C. Y. Mou, C. S. Yang, D. M. Huang, Y. C. Chen, Nano Lett., 7(1) (2007) 149-154

65. H. Zeng, S. Sun, Adv. Funct. Mater., 18 ( 2008) 391-400

66. Xu, J. Xie, D. Ho, C. Wang, N. Kohler, E. G.Walsh, J. R. Morgan, Y. E. Chin, S. Sun, Angew. Chem. Int. Ed., 47 ( 2008) $173-176$

67. V. Roullier, F. Grasset, F. Boulmedais, F. Artzner, O. Cador, V. Marchi-Artzner, Chem. Mater., 20 (21) (2008) 6657-6665 
68. F. Grasset, V. Roullier, V. Marchi-Artzner, O. Cador, F. Dorson, S. Cordier, Y. Molard, S. Mornet, A. Demourgues, E. Duguet, M. Mortier, T. Sasaki, H. Haneda, 2ND IEEE INTERNATIONAL NANOELECTRONICS CONFERENCE, 1-3 (2008) 1023-1027

69. B. Fernandez, N. Galvez, R. Cuesta, A. B. Hungria, J. J. Calvino, J. M. Dominguez-Vera, Adv. Funct. Mater., 18(24) (2008) 3931-3935

70. B. Zhang, J. Cheng, X. Gong, X. Dong, X. Liu, G. Ma, Jin Chang, J. Colloids Inter. Sci., 322 (2008) 485-490

71. Y. Ang, L. Giam, Z. M. Chan, A. W. H. Lin, H. Gu, E. Devlin, G. C. Papaefthymiou, S. T. Selvan, J. Y. Ying, Adv. Mater., DOI: 10.1002/adma.200801273

72. S. Mornet, S. Vasseur, F. Grasset, E. Duguet, J. Mater. Chem., 14, (2004) 2167-2175.

73. M. Dahan, S. Levi, C. Luccardini, P. Rostaing, B. Piveau, A. Triller, Science, 3002 (2003), 442

74. Z. Li, Y. Zhang, Angew. Chem., 118 (2006) $7896-7899$

75. T. T. Tan, S. T. Selvan, L. Zhao, S. Gao, J. Y. Ying, Chem. Mater., 19 (2007) 3112-3117

76. C. H. Contag, B. D. Ross, J. Magn. Reson. Imaging, 16 (2002) 378-387

77. S. Cordier, K. Kirakci, D. Méry, C. Perrin, D. Astruc Inorganica Chimica Acta, 359 (2006) 1705-1709

78. D. Méry, L. Plault, C. Ornelas, J. Ruiz, S. Nlate, D. Astruc, J.-C. Blais, J. Rodrigues, S. Cordier, K. Kirakci, C. Perrin, Inorg. Chem., 45 (2006) 1156

79. K. Kirakci, H. Hosoda, S. Cordier, Christiane Perrin, Gunzi Saito. J. Solid State Chem., 179 (2006) $3641-3648$

80. D. G. Nocera and H. B. Gray, J. Am. Chem. Soc., 106 (1984) 824-825

81. T.G. Gray, C. M. Rudzinski, E. E. Meyer, ${ }^{\ddagger}$ R. H. Holm, D. G. NoceraT. C. Gray, J. Am. Chem. Soc., 125 (2003) 4755.

82. P. Sharma, S. Brown, G. Walter, S. Santra, B. Moudgil, Adv. Colloid Inter. Sci., 123-126 (2006) 471-485 


\section{Scheme and figure captions}

Scheme 1. Schematic representation of a fused dimmer (from 21).

Scheme 2. Preparation of suspended nanoparticles by mixing two water-in-oil microemulsions (from 38).

Scheme 3. Preparation of core-shell nanoparticules by $\mathrm{C} / \mathrm{W} / \mathrm{O}$ microemulsion.

Fig. 1. Five-steps colloid-in oil microemulsion.

Fig. 2. Dynamic light scattering of two $\mathrm{CeO}_{2}$ colloidal sols.

Fig. 3a. SEM images of monodispersed silica nanoparticules. 3b. HAADF-STEM image $\gamma$-of $\mathrm{Fe}_{2} \mathrm{O}_{3}-\mathrm{Cs}_{2} \mathrm{Mo}_{6} \mathrm{Br}_{14} @ \mathrm{SiO}_{2}$ nanoparticles.

Fig. 4. Temperature dependence of the ZFCM and FCM curves of an aggregated (right) or silica coated (left) sample recorded under 10 Oe .

Fig. 5. Observation of the memory effect in zinc ferrite nanocrystals.

Fig. 6. Field versus temperature curves of $\gamma-\mathrm{Fe}_{2} \mathrm{O}_{3} @ \mathrm{SiO}_{2}$ nanoparticles.

Fig. 7: Scratch test patterns for a $0-2.5 \mathrm{~N}$ loading frame for a) SLS glass (substrate) annealed 15 $\min$ at $350^{\circ} \mathrm{C}$, and b) nanoparticles-based coating on the same substrate.

Fig. 8: UV-Vis absorption spectrum for core-shell $\mathrm{CeO}_{2} @ \mathrm{SiO}_{2}$ nanoparticles; Insert : HRTEM image of core-shell $\mathrm{CeO}_{2} @ \mathrm{SiO}_{2}$ nanoparticles.

Fig. 9: Red emission of $\gamma-\mathrm{Fe}_{2} \mathrm{O}_{3}-\mathrm{Cs}_{2} \mathrm{Mo}_{6} \mathrm{Br}_{14} @ \mathrm{SiO}_{2}$ particles after an irradiation at $\lambda_{\text {exc }}=546 \mathrm{~nm}$. Insert : Optical microscope images using $\lambda$ exc $=405 \mathrm{~nm}$ of dispersed nanoparticles under a magnetic field $(1.5 \mathrm{~T})$ showing the growth of a nanoparticles layer along the wall of a cell as a function of time. 


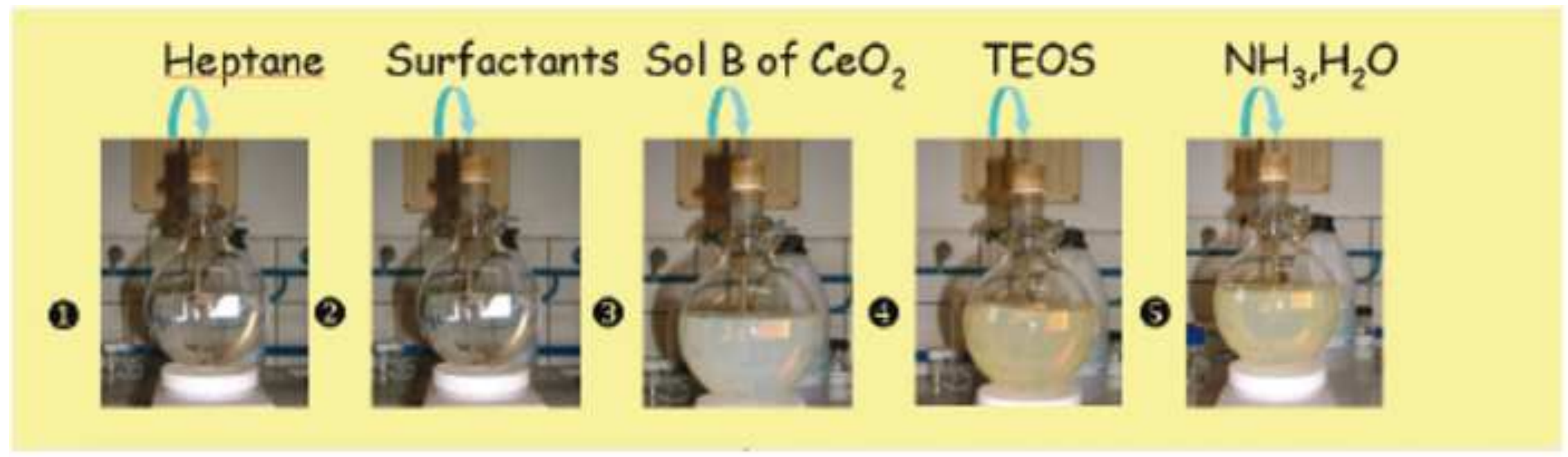

Fig. 1. Five-steps colloid-in oil microemulsion. 


\section{Size Distrbution by irternsty}

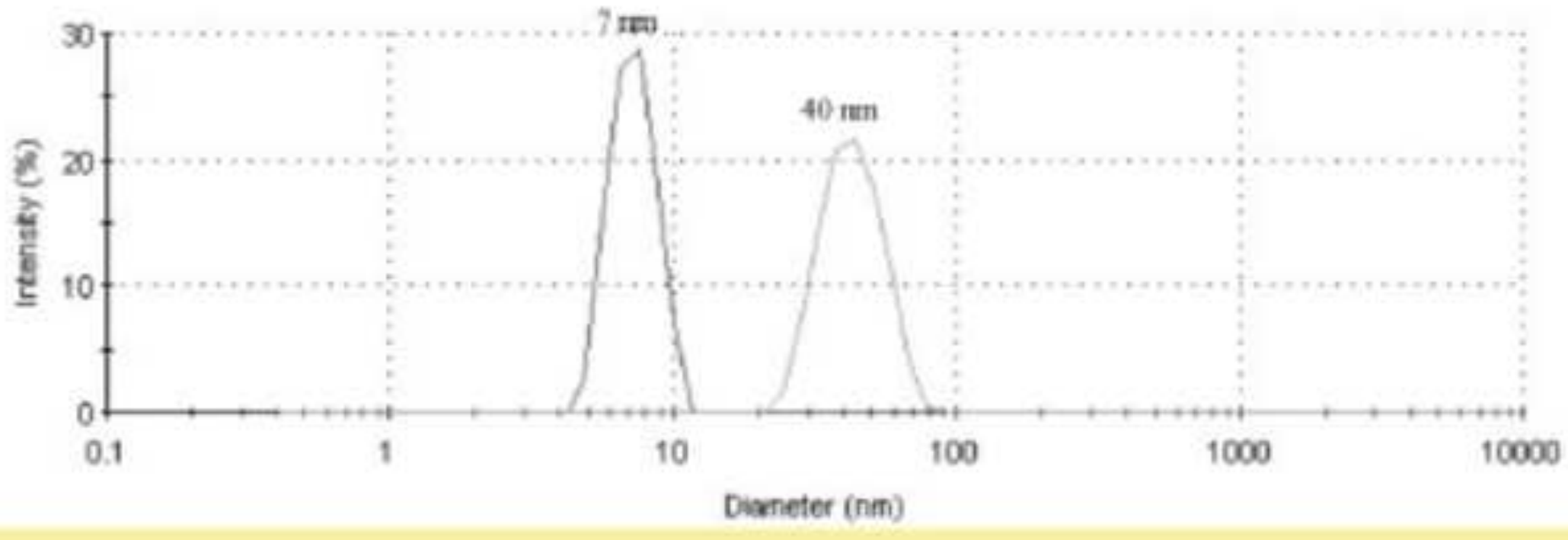

Fig. 2. Dynamic light scattering of two $\mathrm{CeO}_{2}$ colloidal sols. 

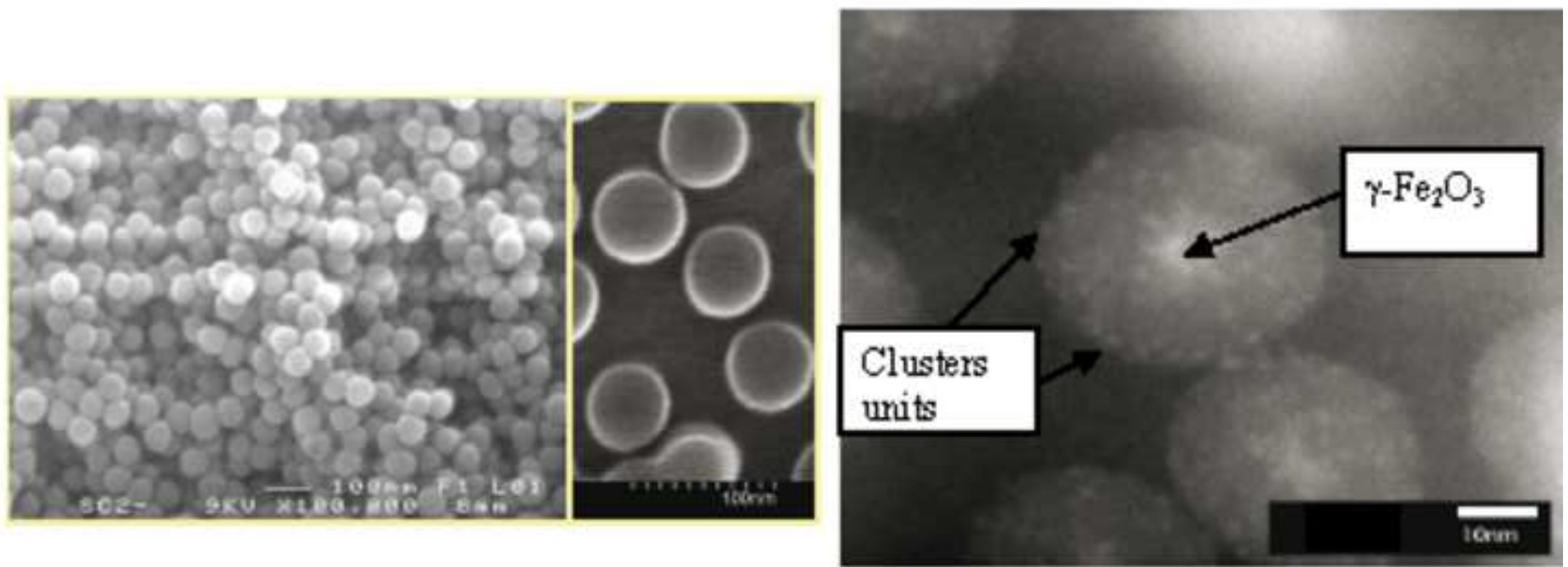

Fig. 3a. SEM images of monodispersed silica nanoparticules. 3b. HAADF-STEM image $\gamma$-of $\mathrm{Fe}_{2} \mathrm{O}_{3}-\mathrm{Cs}_{2} \mathrm{Mo}_{6} \mathrm{Br}_{1} @ \mathrm{SiO}_{2}$ nanoparticles. 

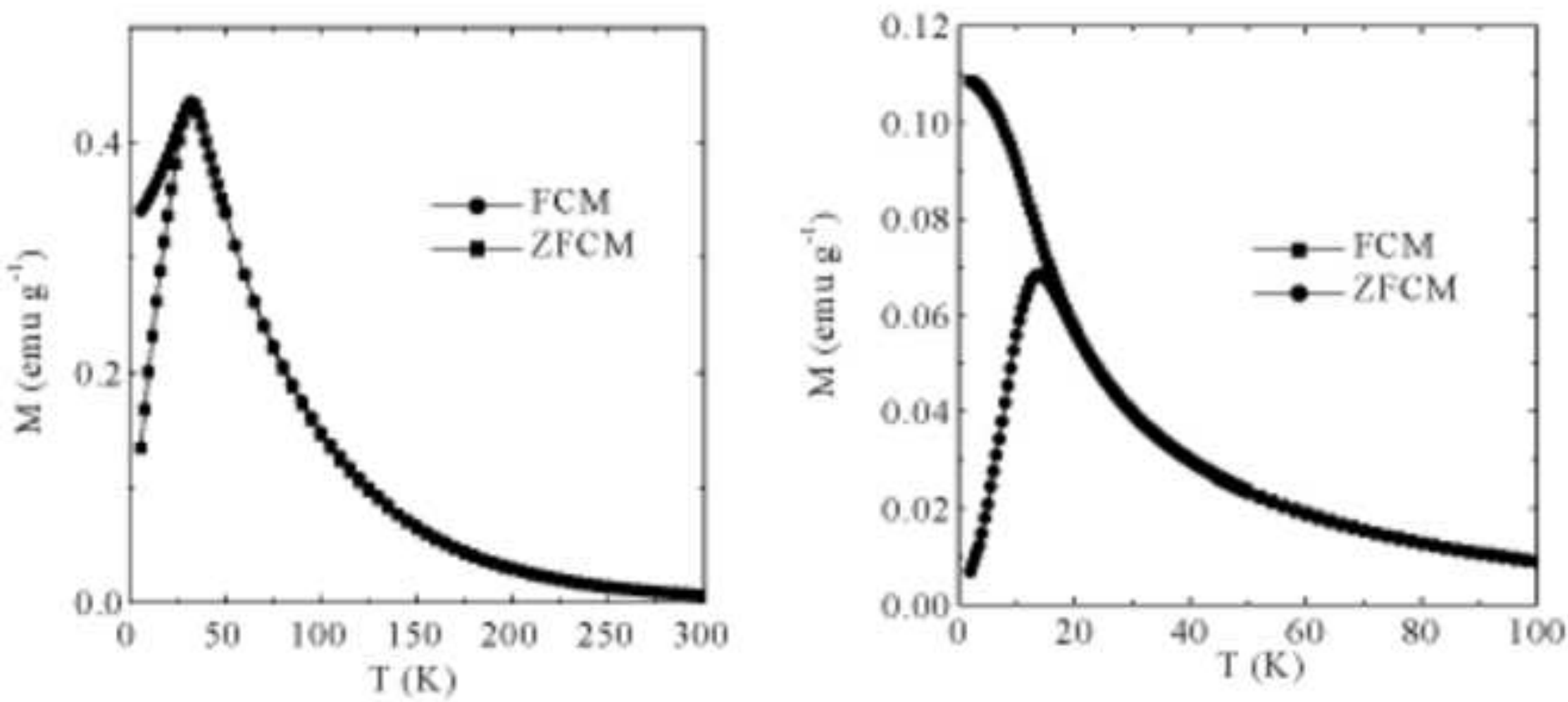

Fig. 4. Temperature dependence of the ZFCM and FCM curves of an aggregated (right) or silica coated (left) sample recorded under $10 \mathrm{Oe}$. 


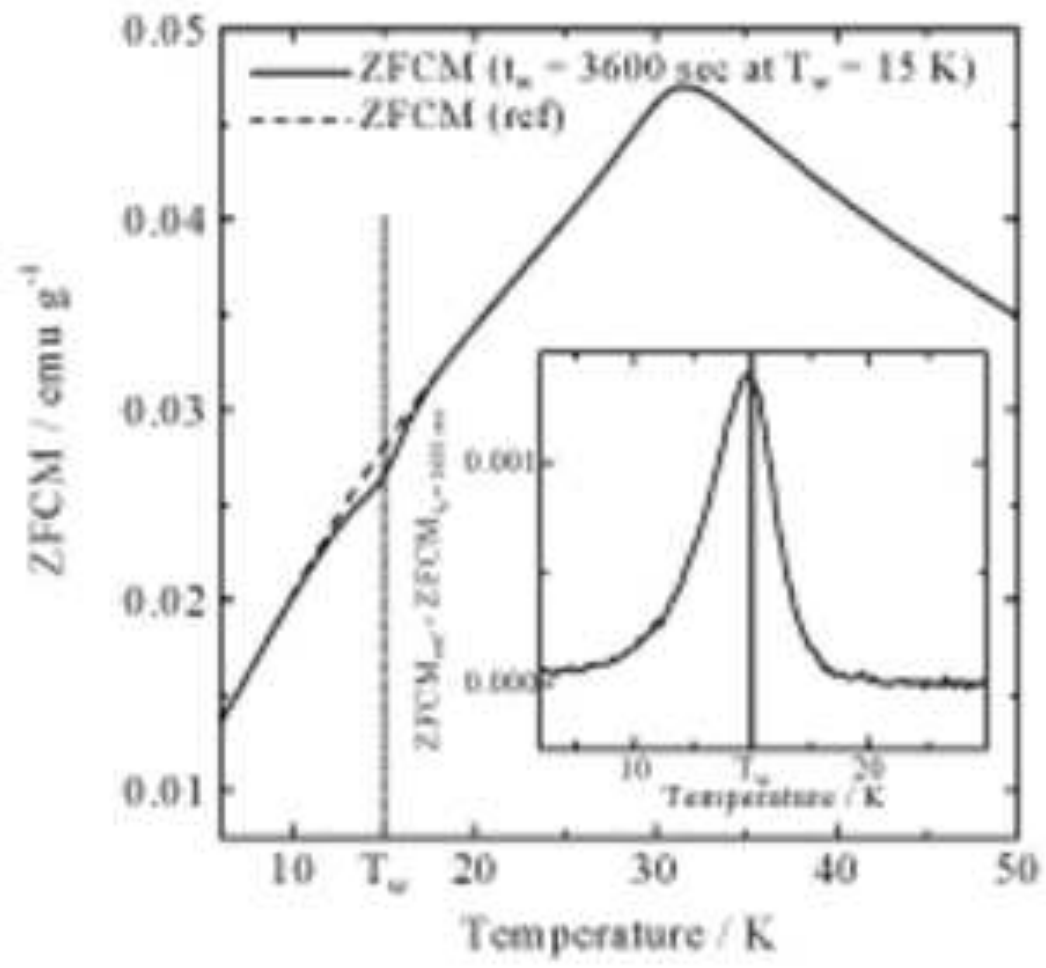

Fig. 5. Observation of the memory effect in zinc ferrite nanocrystals. 
Click here to download high resolution image

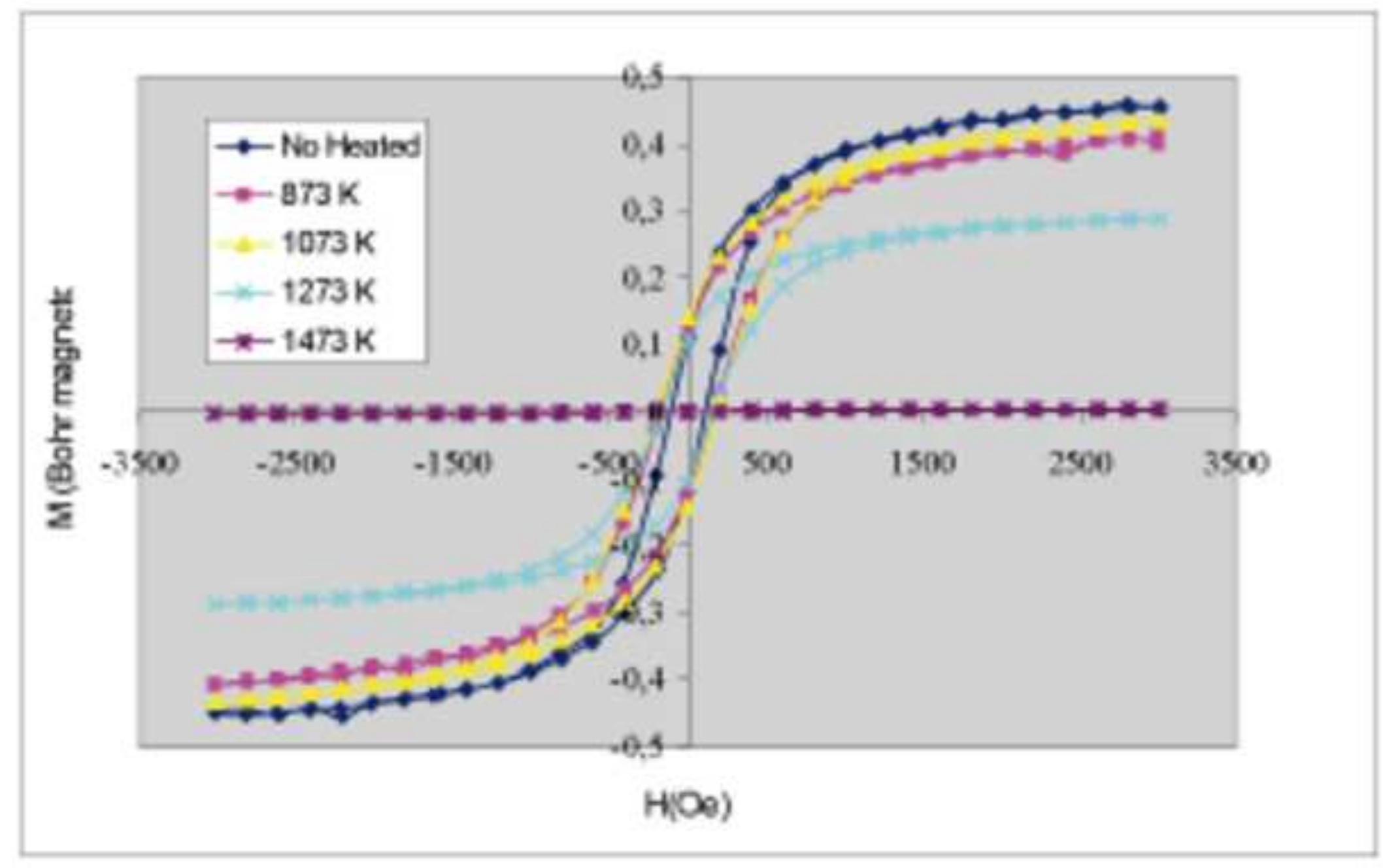

Fig. 6. Field versus temperature curves of $\gamma-\mathrm{Fe}_{2} \mathrm{O}_{3} @ \mathrm{SiO}_{2}$ nanoparticles. 
Click here to download high resolution image

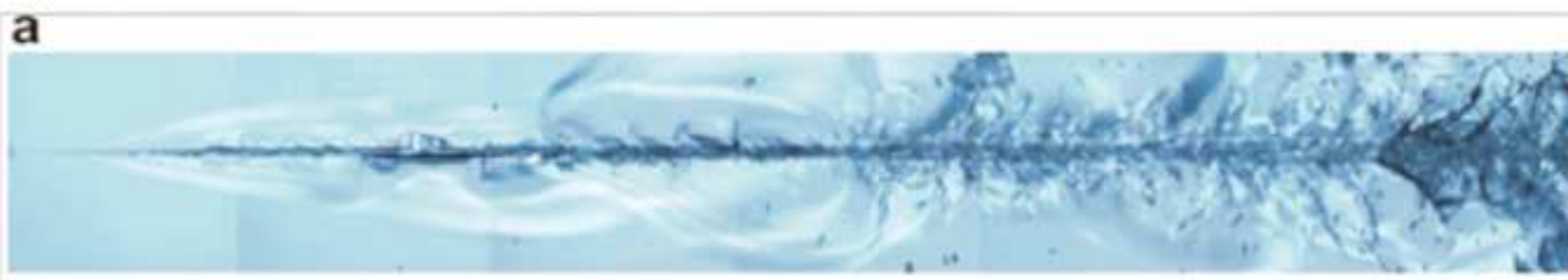

b

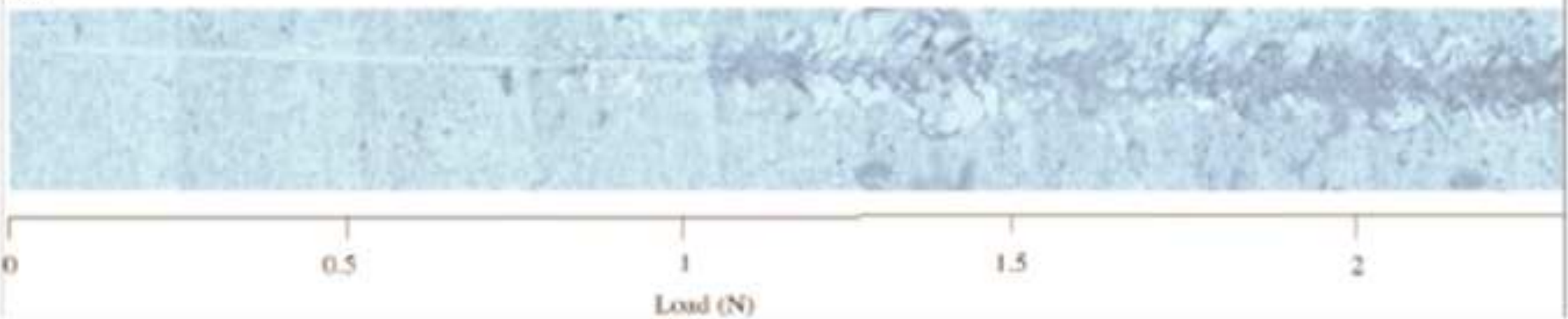

Fig. 7: Scratch test patterns for a 0-2.5 $\mathrm{N}$ loading frame for a) SLS glass (substrate) annealed 15 min at $350^{\circ} \mathrm{C}$, and b) nanoparticles-based coating on the same substrate. 


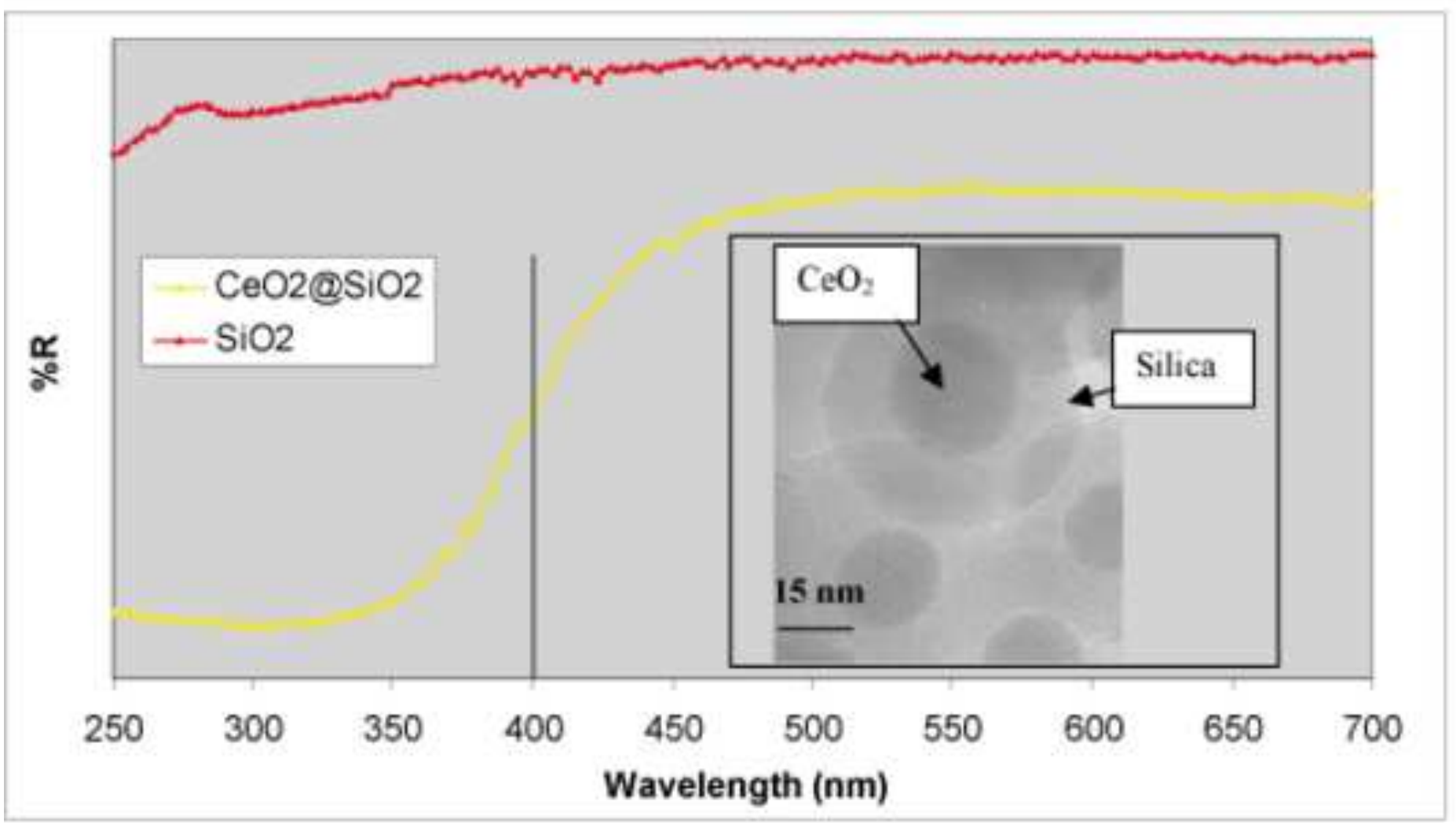

Fig. 8: UV-Vis absorption spectrum for core-shell $\mathrm{CeO}_{2} @ \mathrm{SiO}_{2}$ nanoparticles; Insert : HRTEM image of core-shell $\mathrm{CeO}_{2} @ \mathrm{SiO}_{2}$ nanoparticles. 


\section{5: Figure}

Click here to download high resolution image

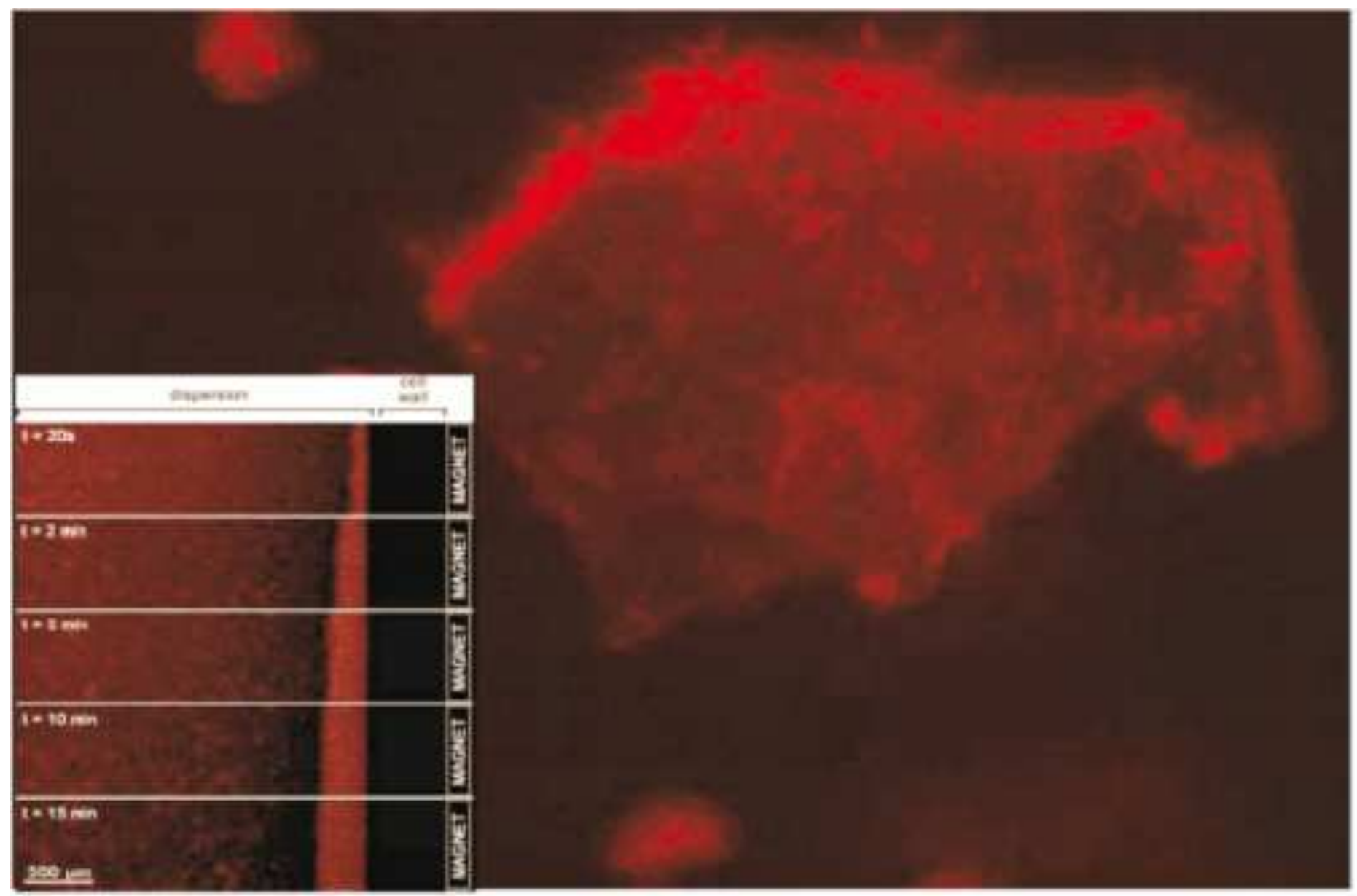

Fig. 9: Red emission of $\gamma-\mathrm{Fe}_{2} \mathrm{O}_{3}-\mathrm{Cs}_{2} \mathrm{Mo}_{6} \mathrm{Br}_{14} @ \mathrm{SiO}_{2}$ particles after an irradiation at $\lambda_{\text {ew }}=546$ $\mathrm{nm}$. Insert : Optical microscope images using $\lambda$ exc $=405 \mathrm{~nm}$ of dispersed nanoparticles under a magnetic field $(1.5 \mathrm{~T})$ showing the growth of a nanoparticles layer along the wall of a cell as a function of time. 
Click here to download high resolution image

\section{Fused diner}

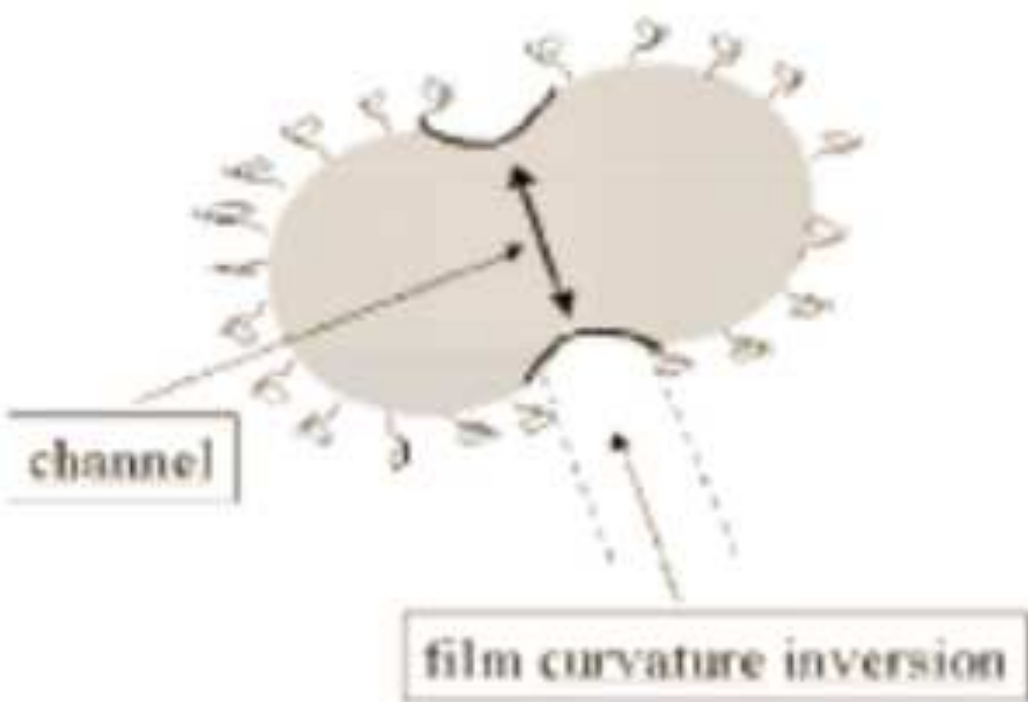

Scheme 1. Schematic representation of a fused dimmer (from 21). 


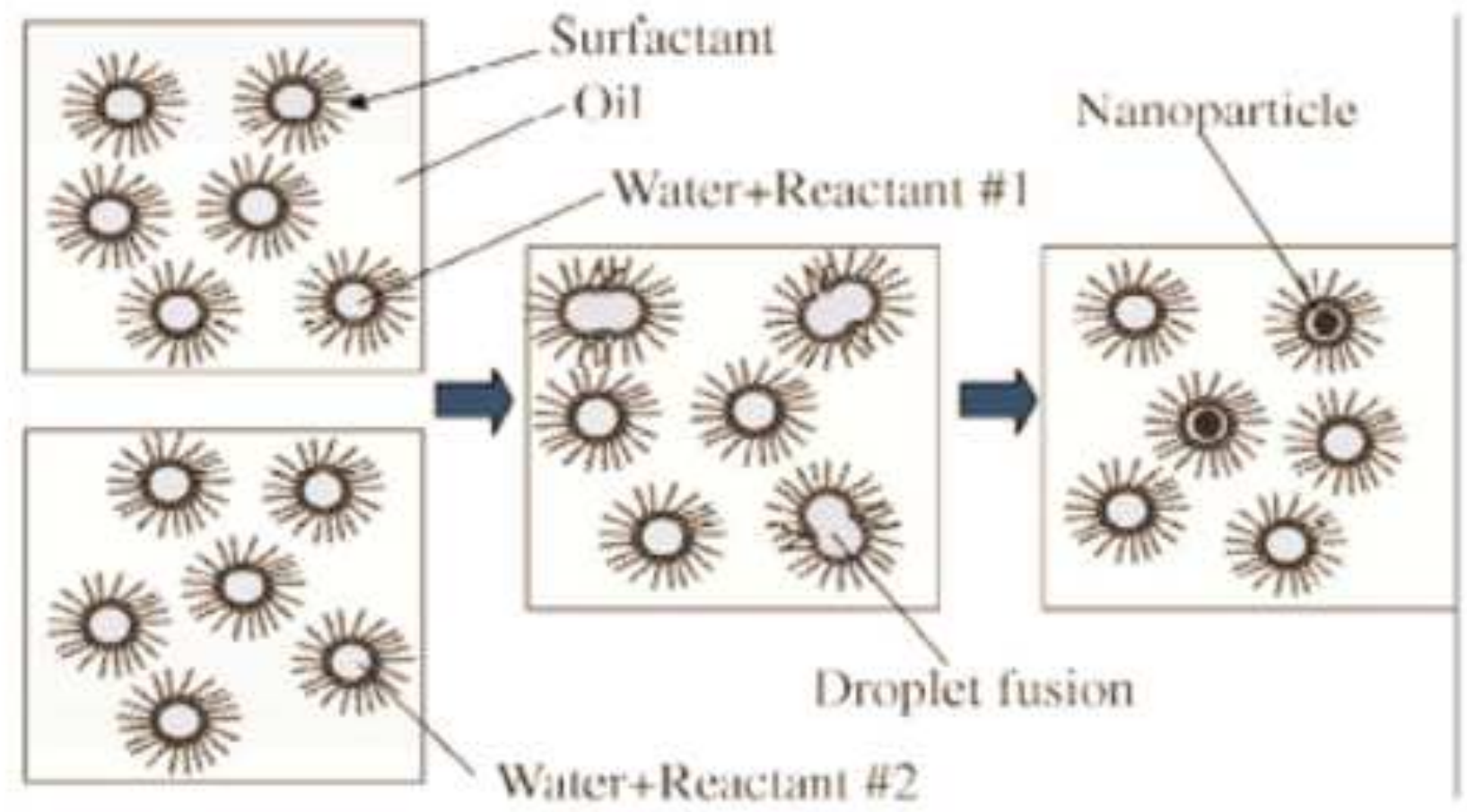

Scheme 2. Preparation of suspended nanoparticles by mixing two water-in-oil microemulsions (from 38). 


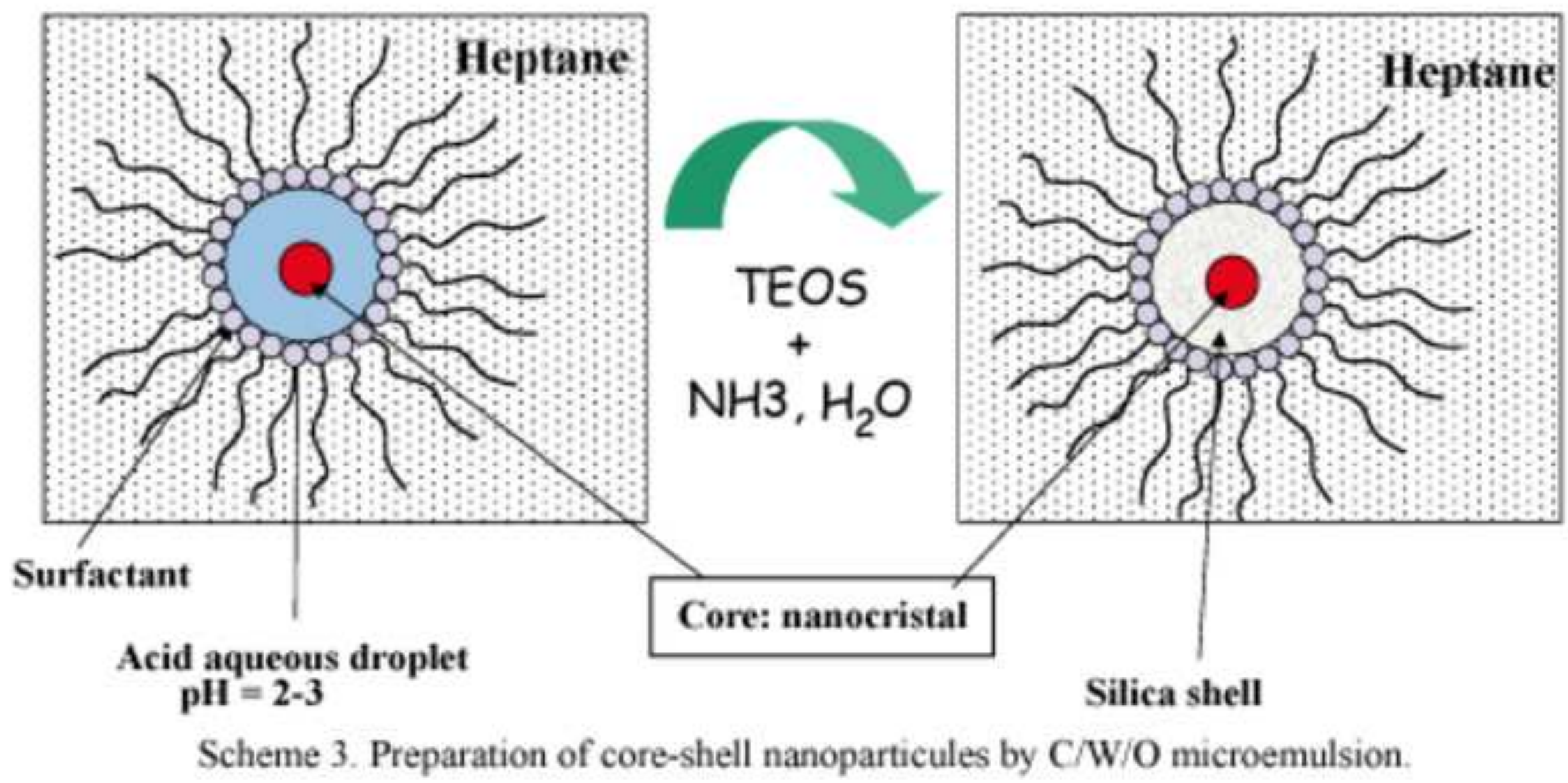

